\title{
INTERNATIONAL ADMINISTRATION
}

$\mathrm{W}$ HEN in July last the American Bar Association visited London, Mr. Herbert Brownell, the Attorney-General of the United States, made a deliberate appeal for a system of law for the nations of the world: this, he said, would be the greatest prize that lawyers could bring to a sorely troubled humanity. We have not yet applied our knowledge of how men may govern themselves by law to the determination of all disputes between countries, and what we need now is the development of the law of nations in order to bind the countries of the world with solemn voluntary pacts, in contrast to unilateral exploitation by the mighty. A civilization which had developed the Common Law and the Bill of Rights should not shrink from this new command of humanity, and the members of the American Bar looked forward to labouring with the English Bar in such a common effort.

It was at a subsequent Guildhall dinner given by the Law Society that Sir Winston Churchill, quoting Mr. Menzies, the Prime Minister of Australia, as saying that justice was not being achieved by the United Nations, made the appeal for changes in the United Nations for which he has been strongly criticized, particularly by those who continue to close their eyes to the contrast between the ideal and reality. Sir Winston did not suggest that Britain should leave the United Nations, but he did point to certain weaknesses in its foundations, and suggested that if the Assembly continued to take its decisions on grounds of enmity, opportunism or merely jealousy and petulance, the whole structure might be brought to nothing. Nor was his appeal for realism unhelpful in the face of Mr. Brownell's appeal. The main point of Sir Winston's speech was the warning against reliance upon any kind of paper agreements which his critics have ignored. "The mere creation of international organizations," said Sir Winston, "does not relieve us of our individual responsibility - at least not until the international systems are truly reliable and effective. It falls to the righteous man individually to do what he can and to form with his friends alliances that are manifestly concerned with justice and honour."

There is a sense, it is true, in which it is not the United Nations that is on trial but the member States which constitute that organization; but nevertheless Sir Winston is not alone in suggesting that, however essential it may be to have some such international organization, there is real danger that the United Nations as it is to-day may collapse. That was fully recognized in the debate in the House of Lords on July 25, and even last December Prof. Gilbert Murray, in writing of the shadow of bar. barism that to-day lies over the whole civilized world, pointed to the weaknesses in the United Nations which flow from the presence of nations of widely varying standards of civilization and resources, but which nevertheless possess equal voting power. Prof. Murray said frankly that to continue moving in the present egalitarian direction and to refuse to admit that unequal things are indeed unequal is likely to endanger all that is best in Western civilization and to plunge the civilized world back into barbarism.

Prof. Murray was too consistent a champion of the League of Nations and of the United Nations for his realism to be distorted into an attack on international co-operation and the establishment of world law and order, and only political prejudice could so construe Sir Winston's realism. Moreover, Sir Ivone Kirkpatrick has also shown exactly how this egalitarian doctrine sets up unforeseen strains in the United Nations, weakens all sense of individual responsibility, and leads to the injustice and collective chaos to which Sir Winston and Mr. Menzies referred. Nevertheless, Sir Ivone, too, thought it would be wrong for Britain and other like-minded countries to leave the United Nations. They should rather use their influence to seek a return to the observance of its charter and in particular to the assumption by the Security Council and the General Assembly of the roles originally allotted to them.

To close one's eyes to inherent weaknesses and to regard as sacrosanct any paper agreement or particular organization, however impracticable amendment may be at any particular moment, does not help the task of establishing justice and the law of nations. Those weaknesses were particularly em. phasized in the debate in the House of Lords, the motion of Earl De La Warr indeed asking the Government to open discussions with other nations at an early appropriate moment to remove these defects, while Lord Glyn's motion referred specifically to the misunderstanding of the respective functions of the Security Council and of the General Assembly. Any reform of the United Nations, it was recognized, is quite impracticable in the foreseeable future; but agreement was equally emphatic that we must seek to make the best possible use of it as it is.

Earl De La Warr made several valuable suggestions. First, he stressed the importance of a full understanding and complete unity between the United States and Britain. In this connexion he referred to the value of removing the misunderstanding of what is termed British colonialism. Next, he emphasized the danger of growth of group politics based on prejudice arising out of geographical, racial or colour considerations. Nothing is so likely to weaken, if not actually destroy, the influence of the United Nations. He laid some stress also on a high standard of representation at the United Nations, on the importance of an international police force, and on the existence of a firm system of law and order, effectively onforced, 
as a precondition of nations relinquishing the right of self-defence.

Lord De La Warr held that the United Nations is indeed on trial to-day, and that it is in many ways an ineffective body. Nevertheless, what the United Nations can do, and can do now, needs to be emphasized, so that it may grow into a body which can ultimately free mankind from the fear of war, and from the type of international behaviour that has so often led to war. In the debate which followed, no one challenged his statement that there are in practice two standards operating in the United Nations: one for the law-abiding nations and another for the law-breakers. Lord Glyn, commenting on the multiplicity of international organizations which normally work closely with the United Nations, seemed to question the need for so many specialized agencies, and to suggest that they might be combined in some manner to strengthen that body and make it more effective. Lord Boyd Orr suggested that, by promoting co-operation between specialized agencies such as the Food and Agriculture Organization and the World Health Organization in the attack on limited practical objectives in human welfare, the United Nations might bring about a better atmosphere in the world and a clearer understanding of the difficulties of different nations. Underlying the whole debate was the recognition that international law can exist only if there is the will to obey the law; and, as Lord Winster said bluntly, it is not respect for law but political and economic considerations that prevail. Even Lord Silkin, in the most optimistic speech of the debate, recognized that the United Nations could not be more than the sum of its members. Thus the debate contributed to a some. what clearer understanding of the relative strength and weakness of the United Nations, and it also brought out, as Lord Attlee mentioned, its dependence on public opinion.

It is as a contribution to that end that two recent books, both of which draw some comparison between the League of Nations and the United Nations, are valuable. In the first of these*, Bernard Moore, giving a lively account of his seven years at the United Nations, shows how the decision to locate the headquarters of the Organization in New York opened the door to some of the lobbying and irresponsibility on which Sir Ivone Kirkpatrick also commented. Mr. Moore obviously believes that the drawbacks far outweigh the advantages of placing the Organization in New York. He brings out both the great importance of the Secretariat and the strain which is imposed on many of its members at Lake Success. But the great value of his book lies in the way he brings to life the human issues in the functioning of such an organization and the importance of the time factor on the larger scale. $\mathrm{He}$, too, emphasizes the importance of more than idealism : goodwill cannot be taken for granted; nations, governments and statesmen need to learn a new technique, to develop

* The Second Lesson: Seven Years at the United Nations. By Bernard Moore. Pp. ix $+229+8$ plates. (London: Macmillan and Co., Ltd., 1957.) 21s. net. a new understanding and to discard old, deeply entrenched habits and ideas.

Mr. Moore's book will show the general reader just why the United Nations needs time to grow. Mr. Loveday's "Reflexions on International Administration" * are concerned with the development of the new technique, and with the factors which determine the morale and efficiency of an international organization. It is not a book for the general public, though it contains much to interest both scientist and technologist. On the major issues that in the past few years have brought the future of the United Nations into question it bears indirectly, though, like Mr. Moore, Mr. Loveday, drawing on his twenty-five years experience as an international official, shows how much an efficient administration can contribute to the prevention of misunderstandings and the establishment of confidence.

Like Mr. Moore, too, Mr. Loveday recognizes that, in spite of a marked tendency at the outset to discount the experience of the League, the United Nations in fact owes much to its predecessor, though he points out that principles and methods of adminis. tration which had proved their worth prior to 1939 are not necessarily valid to-day. The change in the political climate alone would be responsible. What used to be considered technical questions outside the political field may now be subject to power or votingpower politics, and governments are increasingly unwilling to seek an objective study of the problems they have to solve. The best solution is rarely sought, only the easiest compromise; and Mr. Loveday says frankly that the effectiveness of almost all the organs of the United Nations has suffered. Agreement has not been reached because it has not been sought.

It is in what are almost asides that Mr. Loveday illumines the issues debated in the House of Lords, as when discussing staff rules and regulations and the need in any international organization for a body which can discuss administrative problems at the political level. He refers to the danger, in its absence, that the Secretary-General will be unduly exposed both to external pressure to act according to the wishes of individual governments and to unavoidable (or unnecessary) criticism. Certain questions in this context, he admits, are best ventilated in public, "But the vast majority of questions affecting the personnel and a large proportion of diplomatic issues are best settlod behind closed doors". Again, he notes the desirability of relieving the General Assembly of unnecessary detail so that it can concentrate on major issues. His suggestion for easing the problem of recruitment could in itself contribute to the improvement of international understanding and the whole atmosphere of co-operation. As the best means for recruiting nationals from the less-advanced countries, he suggests financing educational facilities at certain universities on a large scale. To succeed, an all-round education and normal Western European educational standards and very liberal financial

* Reflections on International Administration. By A. Loveday. Pp. Xxi +334. (Oxford: Clarendon Press; London: Oxford UniverPp, xxi +334. (Oxford: Clare 
support would be necessary, for only the outstanding graduates from these university centres should stand a chance of selection. There must be a large group from which to select, and the education given must be of real value to those graduates who are not recruited and return home.

The implications of any such scheme are farreaching and, however it might be financed, its organization would require the help of an independent international body such as the International Association of Universities or the International Association of University Professors and Lecturers. The suggestion is one that merits the attention both of the Technical Assistance Board and of Unesco, though Mr. Loveday adds that it might be more practical, in the first place, to attempt to create a European rather than a world Civil Service and for this purpose possibly a common machinery for recruitment. Another important observation is in regard to the Trusteeship Council. The failure of that body, which Mr. Loveday contrasts unfavourably with the Permanent Mandates Commission, to win a respect proportionate to the importance of its functions is attributed partly to its practice of allowing substitutes. It is no more proper, he remarks, for a body the composition of which changes to pass judgment on the manner in which a third party has carried out its obligations than it would be for a jury with changing composition to record a verdict.

These citations can but illustrate the quality of Mr. Loveday's book, and the way it stimulates the clear thinking and honesty of purpose that are two essential steps towards improving the effectiveness of the United Nations. They are, of course, incidental to his main theme, which is discussed in two parts, the first dealing with personnel policy and the second with the operation of the administration. In the first, which discusses sympathetically and with insight and common sense the characteristics and special features of the life of an international official, the qualities required, the maintenance of morale and the problem of recruitment as already noted; the chapters on recruitment and maintenance of morale emphasize several points of great interest in connexion with technical assistance and the recruitment of professional men for overseas work. Mr. Loveday, for example, directs attention to the importance in international administration of constructive imagination, to the implications of the tendency almost throughout the world for higher education to degenerate into technical training, to the relative importance of being able to offer a career as such, as distinct from an officer's professional career ; much that he observes in regard to grading and promotion also has a bearing on professional employment generally.

In the second part of the book Mr. Loveday has some comments on advisory committees and on councils and boards, particularly on the place of the scientific or technical expert, which do not always run with the views expressed by Prof. K. C. Wheare in his "Government by Committee". It is these chapters and that on research which the professional man, whether scientist or not, will find of most interest, for there is also much in this part to interest the manager or administrator in general. Mr. Loveday's shrewd common sense rarely fails to stimulate thought about related issues in industrial, national or international administration, and if the dangers he notes are to be eliminated much help will be required from professional organizations. The danger of selecting directors on account of their technical reputation alone, of preferring a man with a world reputation for his contribution to some branch of knowledge to a less well-known but younger man who possesses to a greater degree the indispensable qualities of leadership, creative imagination and willingness to co-operate with others, are not easily avoided without such professional assistance and goodwill.

On the question of research, apart from noting the reluctance of governments to appoint independent experts able to view controversial matters in a spirit of scientific detachment, Mr. Loveday is averse to the multiplication of institutions at the international level. He recognizes that in the social sciences an international secretariat may, in a limited field, be more competent. Such institutions can and should conduct a type of research for which universities are ill equipped; but, in general, universities are better able to provide the type of competence required. In the natural and applied sciences it is still more exceptional for the establishment of an international laboratory to offer any advantage over the use of an existing institution. The slightest acquaintanceship with the activities of the Nuffield or Rockefeller Foundations should confirm the soundness of this view, and indicate how the organization of research in this way could contribute slowly but surely to international understanding and goodwill.

Mr. Loveday indicates ways in which the United Nations could be enabled to function more effectively and the risk of misunderstandings and internal tension reduced. He makes no large claims that the objectives of its charter will be approached other than gradually in course of time by a long process of co-operative effort. His book, with its clear statements of the conditions in which an international secretariat can function efficiently, none the less indicates small ways in which the individual can sometimes assist to that end. It should contribute to that honesty of purpose, realism and clear thinking for which Sir Winston Churchill, like Prof. Gilbert Murray, appealed, and which must reinforce our idealism if the United Nations is ever to fulfil the hopes in which it was founded. Written before the Suez crisis, it leaves no room for doubt that, if the United Nations is not to collapse, its member States must recollect that the existence of an intermational organization presupposes the acceptance and observance of certain common standards: the urgent need is not for amendment of its charter but for a now and constructive approach to the whole purpose and function of the United Nations Organization and its agencies. 